\title{
Article \\ Phytochemical Analysis of Polyphenols in Leaf Extract from Vernonia amygdalina Delile Plant Growing in Uganda
}

\author{
Jadwiga Nowak ${ }^{1}$, Anna K. Kiss ${ }^{2}$ (D) Charles Wambebe ${ }^{1}$, Esther Katuura ${ }^{3}$ and Łukasz Kuźma ${ }^{4, * \mathbb{D}}$ \\ 1 Department of Pharmacology \& Therapeutics, School of Biomedical Sciences, College of Health Sciences, \\ Makerere University, Kampala P.O. Box 7062, Uganda; Jagodanowak@hotmail.com (J.N.); \\ tsados@gmail.com (C.W.) \\ 2 Department of Pharmacognosy and Molecular Basis of Phytotherapy, Medical University of Warsaw, \\ Banacha 1 St., 02-091 Warsaw, Poland; akiss@wum.edu.pl \\ 3 Department of Plant Sciences, Microbiology and Biotechnology, College of Natural Sciences, \\ Makerere University, Kampala P.O. Box 7062, Uganda; katuurae@gmail.com \\ 4 Department of Biology and Pharmaceutical Botany, Medical University of Łódź, Muszyńskiego 1 St., \\ 90-151 Łódź, Poland \\ * Correspondence: lukasz.kuzma@umed.lodz.pl
}

Citation: Nowak, J.; Kiss, A.K.; Wambebe, C.; Katuura, E.; Kuźma, Ł. Phytochemical Analysis of Polyphenols in Leaf Extract from Vernonia amygdalina Delile Plant Growing in Uganda. Appl. Sci. 2022, 12, 912. https://doi.org/10.3390/ app12020912

Academic Editor: Rosanna Di Paola

Received: 21 December 2021

Accepted: 12 January 2022

Published: 17 January 2022

Publisher's Note: MDPI stays neutral with regard to jurisdictional claims in published maps and institutional affiliations.

Copyright: (C) 2022 by the authors. Licensee MDPI, Basel, Switzerland. This article is an open access article distributed under the terms and conditions of the Creative Commons Attribution (CC BY) license (https:// creativecommons.org/licenses/by/ $4.0 /)$.

\begin{abstract}
Due to the presence of phytochemicals, plants have been known to be used in the treatment and management of various diseases. Vernonia amygdalina, belonging to the Asteraceae family, is a plant known for its many applications in traditional medicine for various purposes. Previous studies on the methanolic leaf extract of this plant have proved the antibacterial, cytotoxic, anticancer and antioxidant effects indicative of promising therapeutic potentials. In this work, chromatographic and spectroscopic techniques along with high-performance liquid chromatography quantitative analysis were adopted to isolate, identify and quantify polyphenolic compounds in $V$. amygdalina leaf extract. UHPLC-DAD-ESI-MS/MS and UHPLC-DAD methods were adopted for qualitative and quantitative analysis, respectively. In the case of polyphenol separation, some reference substances were isolated by preparative HPLC. Seven polyphenols were identified and quantified in this study: 5-O-caffeoylquinic acid, luteolin hexoside, 3,4-O-dicaffeoylquinic acid, 1,5-O-dicaffeoylquinic acid, 3,5-O-dicaffeoylquinic acid, 4,5-O-dicaffeoylquinic acid and luteolin dihexoside, with 3,5-Odicaffeoylquinic acid being isolated in the highest quantity of $27.49 \mathrm{mg} \mathrm{g}^{-1}$ extract.
\end{abstract}

Keywords: methanolic extract; polyphenols; preparative-HPLC; UHPLC-DAD; UHPLC-DAD-MS; Vernonia amygdalina

\section{Introduction}

Medicinal plants have been used to prevent and treat various health problems for many ages [1-3], and despite the great advancement in modern medicine, phytotherapy is still commonly used [3]. Various phytochemicals produced by plants may vary both qualitatively and quantitatively according to many factors such as weather, ecology, time and age of collection [4]. Their active components, including phytosterols, essential oils and phenolics, have been investigated as potential therapeutic agents and towards isolation of novel compounds that can be later structurally modified for therapeutic purposes [5]. Both monophenolic and polyphenolic components from a large number of plants have been proven to delay or lessen the initiation, progression and spread of cancers in both in vitro and in vivo studies [6]. This anti carcinogenic activity is primarily due to the ability of phenolic compounds to induce cell cycle arrest, inhibit oncogenic signalling cascades controlling cell proliferation, angiogenesis and apoptosis, modulate ROS levels, promote tumour suppressor proteins such as p53 and enhance the ability to differentiate and transform into normal cells [7]. Additionally, the body's immune system ability to recognize and destroy cancer cells is enhanced by phenolics, and they appear to increase 
the efficacy of standard chemo- and radiotherapeutic regimens and avert resistance to these agents [8,9]. One of such promising plant is Vernonia amygdalina, especially its aerial parts (the leaves). This bushy shrub or small tree, with green and bitter elliptic petiolate leaves about $6 \mathrm{~mm}$ in diameter, grows to 2-5 $\mathrm{m}$ in height. The stems have light grey or brown bark, which is rather rough and longitudinally flaking, as well as brittle branches. It bears small thistle-like, creamy-white flower heads that are sometimes slightly touched with mauve. The fruit is a small nutlet, with miniature glands and coarse hairs on the body and a long tuft of bristly hairs at the top [10]. In other studies, V. amygdalina is documented to demonstrate diverse therapeutic activities, including anti-cancer properties, that have been attributed to its presence of coumarins, flavonoids, sesquiterpene lactones and edotides [11]. Colorimetric MTT assay measuring cell metabolic activity found that $V$. amygdalina leaf extract inhibits the proliferation and induces apoptosis of MCF-7 and MDAMB-231 human breast cancer cell lines in a time- and dose-dependent manner through both extrinsic and intrinsic pathways [12]. The same study pointed that $V$. amygdalina inhibits the expression of ER- $\alpha$ and its downstream products, and given that ER- $\alpha$ is expressed in around $70 \%$ of diagnosed breast cancers, that has been a crucial finding. The same plant also exhibited compatibility with doxorubicin, indicating that it can complement current chemotherapy [12].

Although previous phytochemical analyses of $V$. amygdalina leaf extract have examined its flavonoids, lipids, mucilage and polyphenol content [13], no detailed qualitative or quantitative analyses of its polyphenols have been performed. Moreover, as part of efforts in our laboratory to understand the effect of combining this plant methanolic extract with other plant extracts and compounds on breast cancer [14] and its possible medicinal use in the management of this disease, detailed knowledge of its active constituents is needed. Therefore, the present study performed qualitative and quantitative analysis of the phenolic compounds in V. amygdalina methanolic leaf extract of Ugandan origin.

\section{Material and Methods}

\subsection{Plant Material}

Plant materials (leaves) were collected from an organically certified farm in Nakaseke district, Uganda, and taken to Herbarium at Makarere University (MHU) for authentication. The voucher specimen of examined plant material was allocated numbers JN/002.

\subsection{Preparation of the Plant Material and Extraction Procedure}

The plant material was collected in the morning, washed and air-dried in the shaded area at ambient temperature $\left(25-30{ }^{\circ} \mathrm{C}\right)$ for 6 days to obtain constant weight. The dried leaves were pulverized (using mortar and pestle) and kept in an airtight container at room temperature until the extraction.

Plant powder $(500 \mathrm{~g})$ was soaked in $2.5 \mathrm{~L}$ of methanol for 3 days. The acquired solution was filtered using Whatman filter paper (No.1) and concentrated in vacuo at a temperature below $45^{\circ} \mathrm{C}$ to obtain the green gum crude residue. The obtained methanolic extracts were stored at $-4{ }^{\circ} \mathrm{C}$ until used for phytochemical analysis.

\subsection{UHPLC-DAD-ESI-MS Qualitative Analysis of V. amygdalina Leaf Extract}

Two milligrams of crude extract were dissolved in methanol and qualitatively analysed by UHPLC-DAD-ESI-MS/MS. Chromatographical analysis was performed on a UHPLC3000 RS system (Dionex, Germany) with DAD detection and an AmaZon SL ion trap mass spectrometer with an ESI interface (Bruker Daltonik $\mathrm{GmbH}$, Germany). Separation was performed on a Zorbax SB-C18 column $(150 \times 2.1 \mathrm{~mm}, 1.9 \mu \mathrm{m})$ (Agilent, Santa Clara, CA, USA). The mobile phase consisted of water (A) and acetonitrile (B) and used the following gradients: 0-60 $\mathrm{min}, 5-40 \% \mathrm{~B}$. The LC eluate was introduced into the ESI interface without splitting, and compounds were analysed in negative ion mode with the following settings: nebulizer pressure of 40 psi; drying gas flow rate of $9 \mathrm{~L} / \mathrm{min}$; nitrogen gas temperature of $300{ }^{\circ} \mathrm{C}$; and a capillary voltage of $4.5 \mathrm{kV}$. The mass scan ranged from 100 to $2200 \mathrm{~m} / \mathrm{z}$. 
The UV spectrum was recorded in the range of 200-400 $\mathrm{nm}$ and the chromatogram was acquired at $325 \mathrm{~nm}$. Compounds were identified by comparing their mass spectroscopic data with those described in the literature.

\subsection{Preparative-HPLC Isolation of the Identified Compounds}

To isolate some of the polyphenols present in studied botanicals, for which standards are not commercially available, the leaf extracts were subjected to preparative-HPLC separation. For this purpose, each of the plant methanolic extracts was dissolved in $25 \mathrm{~mL}$ of methanol and water $(8: 2, v / v)$; afterwards, $25 \mathrm{~mL}$ of cyclohexane was added to the solution and vortexed for $3 \mathrm{~h}$ to eliminate chlorophyll and non-polar contaminants. The watermethanolic part of the solution was separated from the non-polar cyclohexane dark-green fraction and concentrated in vacuo. The purified polar fraction was dissolved in methanol and water $(4: 2 v / v)$ and filtered through a $0.22 \mu \mathrm{m}$ syringe filter and chromatographically separated using a preparative-HPLC chromatograph equipped with a binary pump (Gilson, France), a column thermostat (JetStream 2 Plus), and a UV-Vis detector (Azura Knauer, Germany). The working parameters, with the exception of the column thermostat, were controlled by LP-chrom 2.51 software. The polar part of the extract was separated on the semi-preparative HPLC column $(250 \times 9.0 \mathrm{~mm}$ id; $5.0 \mu \mathrm{m}$; Agilent Technologies $)$ at $35{ }^{\circ} \mathrm{C}$ using the two-ingredient mobile phase consisting of water and methanol, both acidified by formic acid $(0.1 \%)$. The chromatographical isolation was carried out by linear gradient according to the following program: $0-90 \mathrm{~min}, 0-40 \%$ methanol at the flow rate of $3 \mathrm{~mL} \mathrm{~min}{ }^{-1}$. The UV detection of the isolated compounds was performed at $325 \mathrm{~nm}$.

\subsection{UHPLC-DAD Quantitative Determination of Polyphenols in Plant Extract}

The five parts, $5 \mathrm{mg}$ each, of crude green gum residue from plant extract were dissolved in $1 \mathrm{~mL}$ of methanol, filtered through $0.22 \mu \mathrm{m}$ syringe filters and quantitatively analysed by UHPLC method for polyphenols identified in this study. UHPLC analyses were performed in Agilent Technologies 1290 Infinity apparatus equipped with diode array detector (DAD), a binary solvent delivery pump, vacuum degasser, an autosampler and a thermostated column compartment. The separation was performed on a Zorbax Eclipse Plus $\mathrm{C}_{18}$ column $(100 \times 2.1 \mathrm{~mm}$ id; $1.8 \mu \mathrm{m}$ Agilent Technologies $)$ and pre-column $(100 \times 2.1 \mathrm{~mm}$ id; $1.8 \mu \mathrm{m}$; Agilent Technologies) at $40{ }^{\circ} \mathrm{C}$. The mobile phase consisted of acetonitrile $(v / v)$ (solvent A) and water (solvent B), both acidified in $0.1 \%$ formic acid. A gradient program used for the separation of the constituents was applied as follows: $0-10 \mathrm{~min} \mathrm{3 \%} \mathrm{A;} 10-45 \mathrm{~min}$ $3-21 \%$ A; $45-60 \min 21-40 \%$ A. The column was equilibrated with 3\% A for 3 min between injections. The flow rate was $0.4 \mathrm{~mL} \mathrm{~min}^{-1}$ and the injection volume was $5 \mu \mathrm{L}$ The detection wavelength was set at $325 \mathrm{~nm}$. The identity of the determined phytocompounds with those detected by the UHPLC-DAD-ESI-MS method was confirmed based on the UV $\left(\lambda_{\max }\right)$ spectra data. The content of identified polyphenols was calculated based on the calibration curves created by UHPLC analysis and expressed as $\mathrm{mg} \mathrm{g}^{-1}$ of dry extract. To determine the calibration curve for quantification of polyphenols in extracts, the luteolin commercial standard (Roth) and non-commercial caffeoylquinic and dicaffeoylquinic acids (isolated by preparative-HPLC in this study) were used. The content of all caffeoylquinic acids was determined by using calibration curves of caffeoylquinic and dicaffeoylquinic acids, earlier isolated by preparative HPLC.

\section{Results}

\subsection{Identification of Phenolic Compounds in V. amygdalina Leaf Extract}

The full-scan negative ionization mode of the V. amygdalina leaf extract showed a total of seven compounds, identified as phenolic acids and flavonoids (Figure 1, Table 1). 


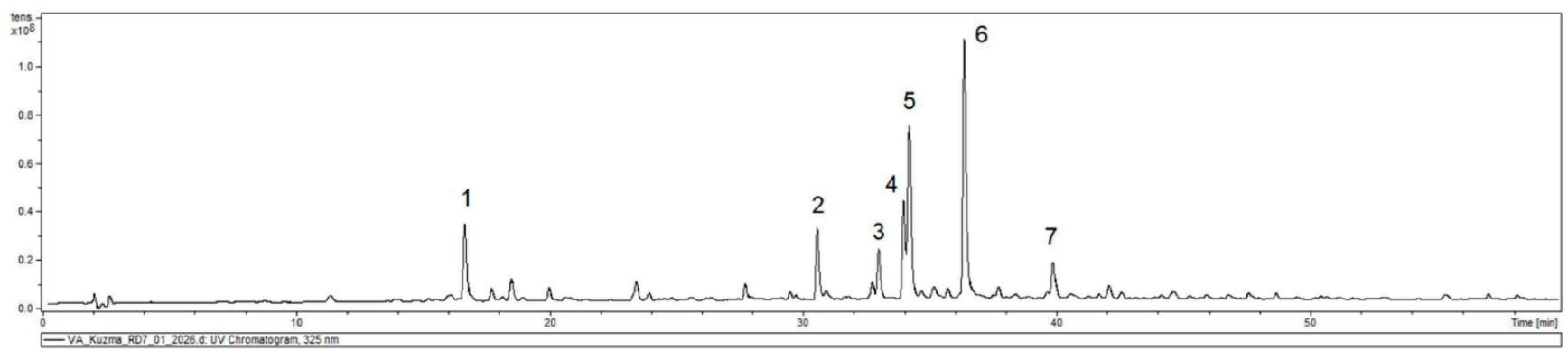

Figure 1. The chromatogram of the qualitative UHPLC-DAD-ESI-MS analysis of $V$. amygdalina methanolic leaf extract. Key: Compound $\mathbf{1}=5$ - $O$-caffeoylquinic acid, Compound $\mathbf{2}=$ luteolin hexoside, Compound $3=3,4-O$-dicaffeoylquinic acid, Compound $4=1,5-O$-dicaffeoylquinic acid, Compound $5=3,5-O$-dicaffeoylquinic acid, Compound $6=4,5-O$-dicaffeoylquinic acid, Compound 7 = luteolin dihexoside.

Table 1. UPLC-DAD-ESI-MS data of detected and identified polyphenolic compounds in V. amygdalina methanolic leaf extract.

\begin{tabular}{cccccc}
\hline Compounds & $\begin{array}{c}\text { Molecular } \\
\text { Formula }\end{array}$ & $\begin{array}{c}\text { Retention } \\
\text { Time }[\mathbf{m i n}]\end{array}$ & $\mathbf{U V}\left(\boldsymbol{\lambda}_{\text {max }}\right.$ in nm) & ${\text { [M-H }]^{-}}^{\text {Fragmentation Ions }}$ \\
\hline 1. 5-0- caffeoylquinic acid & $\mathrm{C}_{16} \mathrm{H}_{18} \mathrm{O}_{9}$ & 16.7 & 325 & 353 & 191 \\
2. luteolin hexoside & $\mathrm{C}_{15} \mathrm{H}_{10} \mathrm{O}_{6}$ & 30.5 & 254,350 & 447 & 285 \\
3. 3,4-O-dicaffeoylquinic acid & $\mathrm{C}_{25} \mathrm{H}_{24} \mathrm{O}_{12}$ & 33.0 & 323 & 515 & $353,191,173,179,135$ \\
4. 1,5-O-dicaffeoylquinic acid & $\mathrm{C}_{25} \mathrm{H}_{24} \mathrm{O}_{12}$ & 33.9 & 328 & 515 & $353,335,191$ \\
5. 3,5-O-dicaffeoylquinic acid & $\mathrm{C}_{25} \mathrm{H}_{24} \mathrm{O}_{12}$ & 34.2 & 327 & 515 & 353 \\
6. 4,5-O-dicaffeoylquinic acid & $\mathrm{C}_{25} \mathrm{H}_{24} \mathrm{O}_{12}$ & 36.3 & 327 & 515 & $353,191,179,173$ \\
7. luteolin dihexoside & $\mathrm{C}_{27} \mathrm{H}_{3} 0 \mathrm{O}_{16}$ & 39.9 & 330 & 609 & 447,285 \\
\hline
\end{tabular}

\subsection{Phenolic Acids}

The peak 1 presented an $[\mathrm{M}-\mathrm{H}]^{-}$ion at $m / z 353$ and fragmentation at $m / z 191$ corresponding to 5-O-caffeoylquinic acid as reported in the literature [15]. The weights of the molecular ions $[\mathrm{M}-\mathrm{H}]$ and fragmentation values of the peaks 3,4,5,6 were compared with data described in previous research [16], and they indicate that all these phytocompounds are dicaffeoylquinic acid derivatives (Table 1) [16].

\subsection{Flavonoids}

The molecular ion $[\mathrm{M}-\mathrm{H}]^{-}$at $m / z 447$ and the fragmentation at $m / z 285$ of the peak 2 suggest that this compound is luteolin hexoside, while peak 7 with its value of molecular ion at [M-H] at $m / z 609$ and fragmentation at $m / z 447$ corresponds to luteolin dihexoside [17].

The content of all determined polyphenolic compounds is expressed in $\mathrm{mg} \mathrm{g}^{-1}$ of the dry extract (Figure 2), and their retention times in quantitative UHPLC analysis are shown in Table 1 and Figure 3. Structures of isolated and quantified compounds are presented in Figure 4.

Values are reported as mean $\pm \mathrm{SE}(n=15$ of UHPLC analyses).

Key: Compound $\mathbf{1}=5-\mathrm{O}$-caffeoylquinic acid, Compound $\mathbf{2}=$ luteolin hexoside, Compound $3=3,4-O$-dicaffeoylquinic acid, Compound $4=1,5-O$-dicaffeoylquinic acid, Compound $5=3,5-O$-dicaffeoylquinic acid, Compound $6=4,5-O$-dicaffeoylquinic acid, Compound 7 = luteolin dihexoside. 


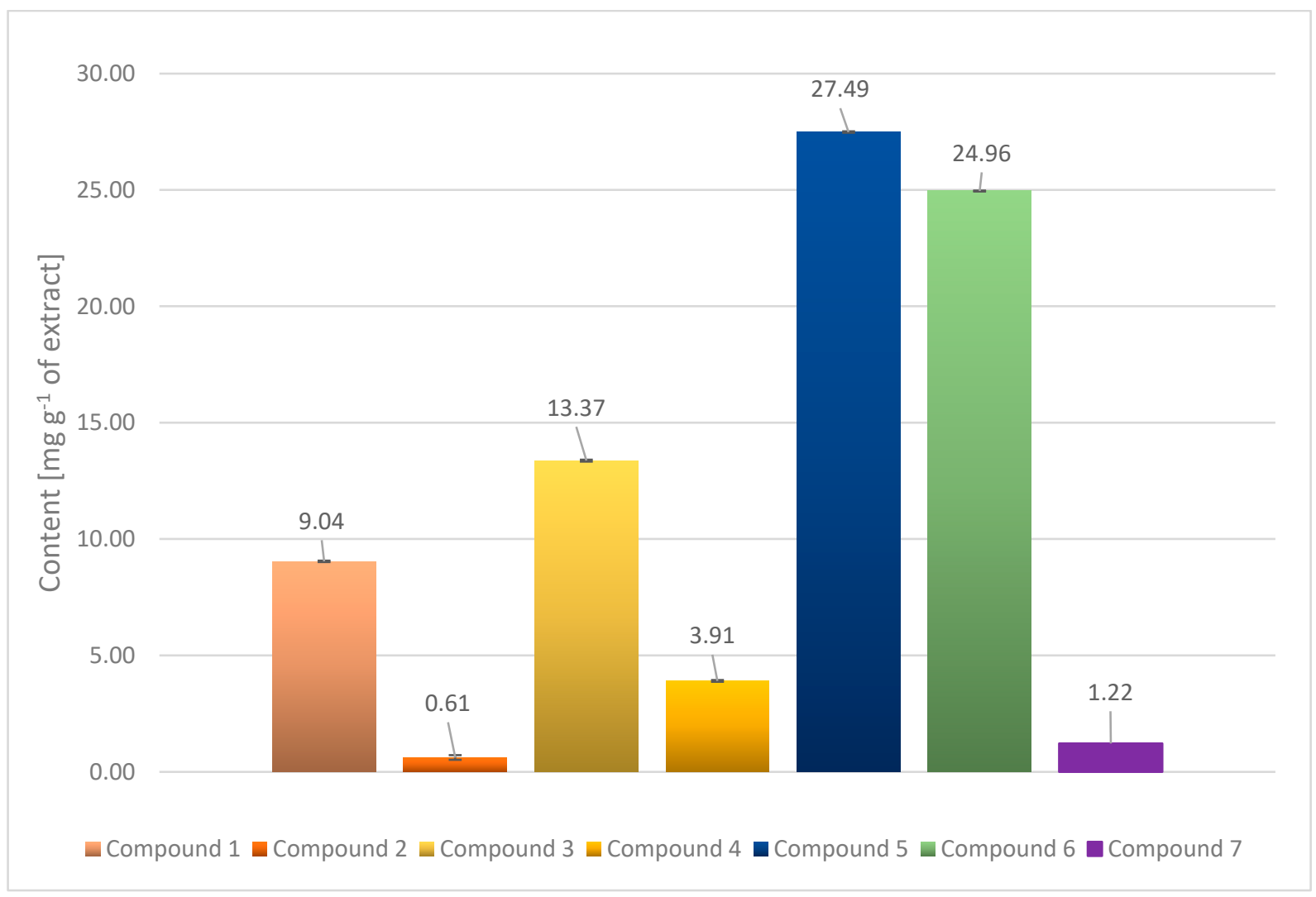

Figure 2. Content of polyphenols in $V$. samygdalina leaf extract.

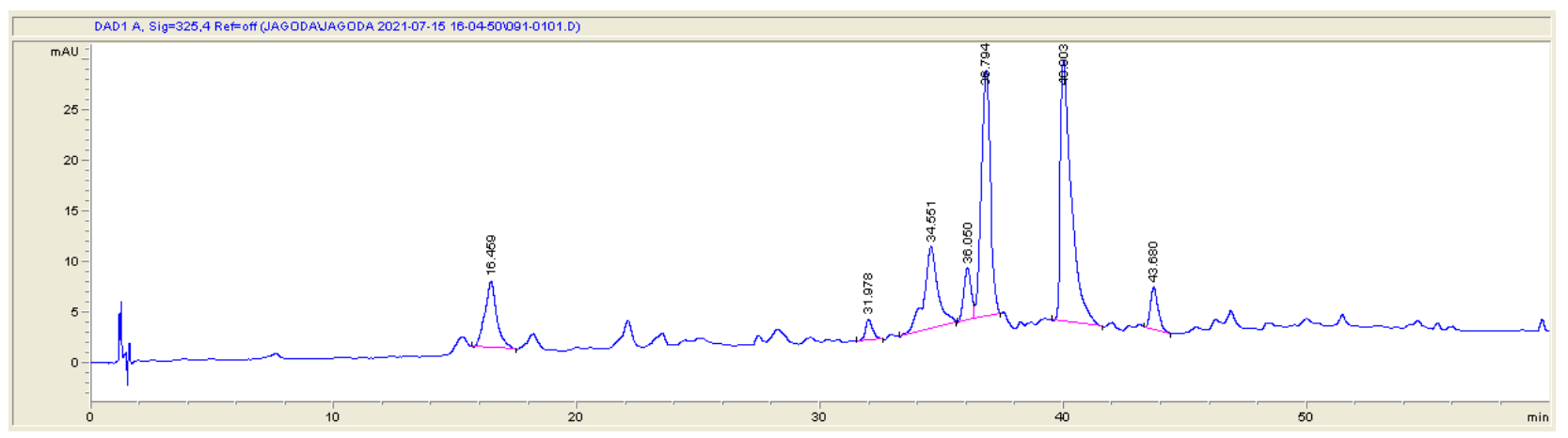

Figure 3. The chromatogram of the quantitative UHPLC analysis of $V$. amygdalina methanolic leaf extract. Key: Compound 1=5-O-caffeoylquinic acid, Compound $\mathbf{2}=$ luteolin hexoside, Compound 3 =3,4-O-dicaffeoylquinic acid, Compound $4=1,5-O$-dicaffeoylquinic acid, Compound 5 = 3,5-Odicaffeoylquinic acid, Compound $6=4,5-O$-dicaffeoylquinic acid, Compound $7=$ luteolin dihexoside. 
<smiles>O=C(/C=C/c1ccc(O)c(O)c1)OC1CC(O)(C(=O)O)C[C@@H](O)C1O</smiles>

5-O-caffeoylquinic acid (1)<smiles>O=C(/C=C/c1ccc(O)c(O)c1)OC1CC(OC(=O)/C=C/c2ccc(O)c(O)c2)(C(=O)O)C[C@H](O)C1O</smiles>

1,5-O-dicaffeoylquinic acid (4)<smiles>O=C(/C=C\c1ccc(O)c(O)c1)OC1=C(OC(=O)/C=C/c2ccc(O)c(O)c2)C[C@@](O)(C(=O)O)C[C@H]1O</smiles>

4,5-O-dicaffeoylquinic acid (6)<smiles>O=C(/C=C/c1ccc(O)c(O)c1)OC1[C@@H](O)C[C@](O)(C(=O)O)C[C@@H]1OC(=O)/C=C/c1ccc(O)c(O)c1</smiles>

3,4-O-dicaffeoylquinic (3)<smiles>O=C(/C=C/c1ccc(O)c(O)c1)O[C@H]1CC(O)(C(=O)O)C[C@H](OC(=O)/C=C/c2ccc(O)c(O)c2)C1O</smiles>

3,5-O-dicaffeoylquinic acid (5)<smiles>O=c1cc(-c2ccc(O)c(O)c2)oc2cc(O)cc(O)c12</smiles>

Figure 4. Structures of isolated and quantified compounds in VA.

\section{Discussion}

Studies have confirmed that people predominantly consuming plant-based foods have low incidence rates of various cancers [18]. Plant phenolic secondary metabolites appear to have both prophylactic and curative potential in the fight against cancer; therefore, phytochemical studies of these natural compounds seem to be justified. This study, for the first time, performed qualitative and quantitative analysis of methanolic leaf extracts from $V$. amygdalina growing in Uganda and have proven a different plant phenolic composition to those investigated previously [19]. The reason for these differences may be the fact that studied plant material was from another part of the world, resulting in a different spectrum and content of these metabolites due to various environmental conditions for plant growth, such as light and photoperiod, temperature, soil, water and salinity [20]. Phenolic 
analysis of botanical used in this study presented caffeoylquinic and dicaffeoylquinic acid derivatives as the main group of compounds $\left(78.75 \mathrm{mg} \mathrm{g}^{-1}\right)$, followed by a much lower amount of luteolin derivatives (1.82 $\mathrm{mg} \mathrm{g}^{-1}$ ) (Figure 2). Caffeoylquinic acid derivatives have been reported to exhibit antioxidant [21-23], cancer-related [24-30], antiviral, antiAlzheimer [31,32] and neuroprotective activity [33-35]. Flavonoids are known for their antioxidant activities and are intensively studied due to their benefit for human health and the treatment of diseases, including cancer and cardiovascular disease [36]. They show potential antioxidant, anti-inflammatory, anti-allergic antiviral, antiplatelet, antitumor effects and support the treatment of neurodegenerative diseases [37].

Flavonol luteolin, identified in this study, among its antioxidant and anti-inflammatory action, shows anticancer activities against MCF-7 cell line, inhibits Akt phosphorylation in a dose-dependent manner, impedes NF- $\mathrm{kB}$ activation, impairs the nuclear translocation of STAT3 and blocks the energy metabolism pathway, which makes this compound a potential candidate for the treatment of inflammatory and proliferative diseases [38].

\section{Conclusions Remarks}

The present work is the first report covering both the qualitative and quantitative profile of polyphenolic compounds in methanolic leaf extract of $V$. amygdalina, a plant growing under the climatic conditions of Uganda. Previous research [10] points out the anticancer and health-promoting activity of the studied botanicals, and thus this study may help with the standardization of $V$. amygdalina Ugandan origin and its potential use as a dietary supplement and/or herbal medicine.

Author Contributions: Conceptualization, J.N. and Ł.K.; methodology, A.K.K., Ł.K., J.N.; software, A.K.K., Ł.K.; validation, J.N., Ł.K., C.W. and E.K.; formal analysis, J.N., Ł.K.; investigation, J.N. Ł.K.; resources, J.N., Ł.K., A.K.K.; data curation, J.N., A.K.K., Ł.K.; writing-original draft preparation, J.N., Ł.K.; writing-review and editing, J.N., Ł.K., C.W., E.K.; visualization, Ł.K.; supervision, C.W., E.K.; project administration, J.N., Ł.K.; funding acquisition, Ł.K. All authors have read and agreed to the published version of the manuscript.

Funding: This work was supported by grant No. 503/3-012-01/503-31-001-19-00 of Medical University of Łódź, Poland.

Conflicts of Interest: The authors declare no conflict of interest.

\section{References}

1. Veiga Junior, V.F.; Pinto, A.C.; Maciel, M.A. Medicinal plants: Safe cure? Quim. Nova 2005, 28, 519-528. [CrossRef]

2. Schmitz, W.; Saito, A.Y.; Estevão, D.; Saridakis, H.O. Green tea and its actions as a chemoprotectant. Semin Cienc Biol Saúde 2005, 26, 119-130. [CrossRef]

3. Alvim, N.A.; Ferreira, M.D.; Cabral, I.E.; Almeida Filho, A.J.D. O uso de plantas medicinais como recurso terapêutico: Das influências da formação professional às implicações éticas e legais de sua aplicabilidade como extensão da prática de cuidar realizada pela enfermeira. Revista Latino-Amer. de Enfer. 2006, 14, 316-323. [CrossRef] [PubMed]

4. Zhang, L.; Wang, X.; Guo, J.; Xia, Q.; Zhao, G.; Zhou, H.; Xie, F. Metabolic profiling of Chinese tobacco leaf of different geographical origins by GC-MS. J. Agric. Food Chem. 2013, 61, 2597-2605. [CrossRef]

5. Saini, S.; Dhiman, A.; Nanda, S. Pharmacognostical and phytochemical studies of Piper betle Linn Leaf. Int. J. Pharm. 2016, 8, $222-226$.

6. Abotaleb, M.; Liskova, A.; Kubatka, P.; Büsselberg, D. Therapeutic potential of plant phenolic acids in the treatment of cancer. Biomolecules 2020, 10, 221. [CrossRef]

7. Nugroho, A.; Heryani, H.; Choi, J.S.; Park, H.J. Identification and quantification of flavonoids in Carica papaya leaf and peroxynitrite-scavenging activity. Asian Pac. J. Trop. Biomed. 2017, 7, 208-213. [CrossRef]

8. Anantharaju, P.G.; Gowda, P.C.; Vimalambike, M.G.; Madhunapantula, S.V. An overview on the role of dietary phenolics for the treatment of cancers. Nutr. J. 2016, 15, 1-6. [CrossRef]

9. Ding, S.; Jiang, H.; Fang, J. Regulation of immune function by polyphenols. J. Immunol. Res. 2018, 2018, 1-8. [CrossRef] [PubMed]

10. Bhattacharjee, B.; Lakshminarasimhan, P.; Bhattacharjee, A.; Agrawala, D.K.; Pathak, M.K. Vernonia amygdalina Delile (Asteraceae)-African medicinal plant introduced in India. Zoo's Print 2013, 28, 18-20.

11. Ijeh, I.I.; Ejike, C.E.C. Current perspectives on the medicinal potentials of Vernonia amygdalina Del. J. Med. Plants Res. 2011, 5, 1051-1061. 
12. Wong, F.C.; Woo, C.C.; Hsu, A.; Tan, B.K.H. The anti-cancer activities of Vernonia amygdalina extract in human breast cancer cell lines are mediated through caspase-dependent and p53-independent pathways. PLoS ONE 2013, 8, e78021. [CrossRef] [PubMed]

13. Erukainure, O.L.; Chukwuma, C.I.; Sanni, O.; Matsabisa, M.G.; Islam, S. Histochemistry, phenolic content, antioxidant, and anti-diabetic activities of Vernonia amygdalina leaf extract. J. Food Biochem. 2019, 43, e12737. [CrossRef]

14. Nowak, J.; Wambebe, C.; Mukonzo, J.; Katuura, E. Cytotoxic activity of combining molecular iodine and dihydroartemisinin with methanol extracts of Carica papaya Linn and Vernonia amygdalina Delile leaves against MCF-7 and MDA-MB-231 breast cancer cell lines. Trop. J. Nat. Prod. Res. 2021, 5, 485-493.

15. Willems, J.L.; Khamis, M.M.; Saeid, W.M.; Purves, R.W.; Katselis, G.; Low, N.H.; El-Aneed, A. Analysis of a series of chlorogenic acid isomers using differential ion mobility and tandem mass spectrometry. Anal. Chim. Acta 2016, 933, 164-174. [CrossRef]

16. Xue, M.; Shi, H.; Zhang, J.; Liu, Q.Q.; Guan, J.; Zhang, J.Y.; Ma, Q. Stability and degradation of caffeoylquinic acids under different storage conditions studied by high-performance liquid chromatography with photo diode array detection and high-performance liquid chromatography with electrospray ionization collision-induced dissociation tandem mass spectrometry. Molecules 2016, $21,948$.

17. Barros, L.; Pereira, E.; Calhelha, R.C.; Dueñas, M.; Carvalho, A.M.; Santos-Buelga, C.; Ferreira, I.C. Bioactivity and chemical characterization in hydrophilic and lipophilic compounds of Chenopodium ambrosioides L. J. Funct. Foods 2013, 5, 1732-1740. [CrossRef]

18. Molina-Montes, E.; Salamanca-Fernández, E.; Garcia-Villanova, B.; Sánchez, M.J. The impact of plant-based dietary patterns on cancer-related outcomes: A rapid review and meta-analysis. Nutrients 2020, 12, 2010. [CrossRef]

19. Soib, H.H.; Ismail, H.F.; Ya'akob, H.; Idris, M.K.H.; Abd Aziz, A. Effect of extraction solvents on antioxidant and wound healing properties of Carica papaya leaves extract. Food Res. 2020, 4 (Suppl. S2), 76-83. [CrossRef]

20. Yang, L.; Wen, K.S.; Ruan, X.; Zhao, Y.X.; Wei, F.; Wang, Q. Response of plant secondary metabolites to environmental factors. Molecules 2018, 23, 762. [CrossRef]

21. Hamed, Y.S.; Abdin, M.; Chen, G.; Akhtar, H.M.; Zeng, X. Effects of impregnate temperature on extraction of caffeoylquinic acid derivatives from Moringa oleifera leaves and evaluation of inhibitory activity on digestive enzyme, antioxidant, anti-proliferative and antibacterial activities of the extract. Int. J. Food Sci. Technol. 2020, 55, 3082-3090. [CrossRef]

22. Nzekoue, F.K.; Angeloni, S.; Navarini, L.; Angeloni, C.; Freschi, M.; Hrelia, S.; Vitali, L.A.; Sagratini, G.; Vittori, S.; Caprioli, G. Coffee silverskin extracts: Quantification of 30 bioactive compounds by a new HPLC-MS/MS method and evaluation of their antioxidant and antibacterial activities. Food Res. Int. 2020, 133, 109128. [CrossRef] [PubMed]

23. Trendafilova, A.; Ivanova, V.; Rangelov, M.; Todorova, M.; Ozek, G.; Yur, S.; Ozek, T.; Aneva, I.; Veleva, R.; Moskova-Doumanova V.; et al. Caffeoylquinic acids, cytotoxic, antioxidant, acetylcholinesterase and tyrosinase enzyme inhibitory activities of six Inula species from Bulgaria. Chem. Biodivers. 2020, 17, e2000051. [CrossRef] [PubMed]

24. Bourgou, S.; Rebey, I.B.; Mkadmini, K.; Isoda, H.; Ksouri, R.; Ksouri, W.M. LC-ESI-TOF-MS and GC-MS profiling of Artemisia herba-alba and evaluation of its bioactive properties. Food Res. Int. 2017, 99, 702-712. [CrossRef] [PubMed]

25. Bulgakov, V.P.; Vereshchagina, Y.V.; Veremeichik, G.N. Anticancer polyphenols from cultured plant cells: Production and new bioengineering strategies. Curr. Med. Chem. 2018, 25, 4671-4692. [CrossRef]

26. Giorgio, C.; Mena, P.; Del Rio, D.; Brighenti, F.; Barocelli, E.; Hassan-Mohamed, I.; Callegari, D.; Lodola, A.; Tognolini, M. The ellagitannin colonic metabolite urolithin D selectively inhibits EphA2 phosphorylation in prostate cancer cells. Mol. Nutr. Food Res. 2015, 59, 2155-2167. [CrossRef] [PubMed]

27. Liu, W.; Li, J.; Zhang, X.; Zu, Y.; Yang, Y.; Liu, W.; Xu, Z.; Gao, H.; Sun, X.; Jiang, X.; et al. Current advances in naturally occurring caffeoylquinic acids: Structure, bioactivity, and synthesis. J. Agric. Food Chem. 2020, 68, 10489-10516. [CrossRef]

28. Murad, L.D.; Soares, N.D.; Brand, C.; Monteiro, M.C.; Teodoro, A.J. Effects of caffeic and 5-caffeoylquinic acids on cell viability and cellular uptake in human colon adenocarcinoma cells. Nutr. Cancer 2015, 67, 532-542. [CrossRef]

29. Taira, J.; Uehara, M.; Tsuchida, E.; Ohmine, W. Inhibition of the $\beta$-catenin/Tcf signaling by caffeoylquinic acids in sweet potato leaf through down regulation of the Tcf-4 transcription. J. Agric. Food Chem. 2014, 62, 167-172. [CrossRef]

30. Zheleva-Dimitrova, D.; Gevrenova, R.; Zaharieva, M.M.; Najdenski, H.; Ruseva, S.; Lozanov, V.; Balabanova, V.; Yagi, S.; Momekov, G.; Mitev, V. HPLC-UV and LC-MS analyses of acylquinic acids in Geigeria alata (DC) Oliv. \& Hiern. and their contribution to antioxidant and antimicrobial capacity. Phytochem. Anal. 2017, 28, 176-184.

31. Matthews, D.G.; Caruso, M.; Alcazar Magana, A.; Wright, K.M.; Maier, C.S.; Stevens, J.F.; Gray, N.E.; Quinn, J.F.; Soumyanath, A. Caffeoylquinic acids in Centella asiatica reverse cognitive deficits in male 5XFAD Alzheimer's disease model mice. Nutrients 2020, 12, 3488. [CrossRef] [PubMed]

32. Tsunoda, T.; Takase, M.; Shigemori, H. Structure-activity relationship of clovamide and its related compounds for the inhibition of amyloid $\beta$ aggregation. Bioorg. Med. Chem. 2018, 26, 3202-3209. [CrossRef] [PubMed]

33. Gray, N.E.; Morré, J.; Kelley, J.; Maier, C.S.; Stevens, J.F.; Quinn, J.F.; Soumyanath, A. Caffeoylquinic acids in Centella asiatica protect against amyloid- $\beta$ toxicity. J. Alzheimers Dis. 2014, 40, 359-373. [CrossRef] [PubMed]

34. Metwally, D.M.; Alajmi, R.A.; ElKhadragy, M.F.; Yehia, H.M.; AL-Megrin, W.A.; Akabawy, A.M.; Amin, H.K.; Moneim, A.E. Chlorogenic acid confers robust neuroprotection against arsenite toxicity in mice by reversing oxidative stress, inflammation, and apoptosis. J. Funct. Foods 2020, 75, 104202. [CrossRef]

35. Sasaki, K.; Davies, J.; Doldán, N.G.; Arao, S.; Ferdousi, F.; Szele, F.G.; Isoda, H. 3,4,5-Tricaffeoylquinic acid induces adult neurogenesis and improves deficit of learning and memory in aging model senescence-accelerated prone 8 mice. Aging 2019, 11, 401. [CrossRef] 
36. Manach, C.; Scalbert, A.; Morand, C.; Rémésy, C.; Jiménez, L. Polyphenols: Food sources and bioavailability. Am. J. Clin. Nutr. 2004, 79, 727-747. [CrossRef]

37. David, A.V.; Arulmoli, R.; Parasuraman, S. Overviews of biological importance of quercetin: A bioactive flavonoid. Pharmacogn. Rev. 2016, 10, 84-89.

38. Palombo, R.; Caporali, S.; Falconi, M.; Iacovelli, F.; Morozzo Della Rocca, B.; Lo Surdo, A.; Campione, E.; Candi, E.; Melino, G.; Bernardini, S.; et al. Luteolin-7-O- $\beta$-D-glucoside inhibits cellular energy production interacting with HEK2 in keratinocytes. Int. J. Mol. Sci. 2019, 20, 2689. [CrossRef] [PubMed] 